DIGITAL COMMONS
@ UNIVERSITY OF SOUTH FLORIDA

Volume 1

Issue 1 Volume 1 (2011): Women's Poetry

\section{ABO: Interactive Journal for Women in the Arts, 1640-1830}

\title{
Numbering the Streaks on a Digital Tulip: Eighteenth-Century Women Poets on the World Wide Web
}

\author{
Emily Bowles \\ emily.bowles@uwc.edu
}

Follow this and additional works at: https://digitalcommons.usf.edu/abo

Part of the Dramatic Literature, Criticism and Theory Commons, Educational Methods Commons, Feminist, Gender, and Sexuality Studies Commons, and the Literature in English, British Isles Commons

\section{Recommended Citation}

Bowles, Emily (2011) "Numbering the Streaks on a Digital Tulip: Eighteenth-Century Women Poets on the World Wide Web," ABO: Interactive Journal for Women in the Arts, 1640-1830: Vol.1: Iss.1, Article 7. http://dx.doi.org/10.5038/2157-7129.1.1.6

Available at: https://digitalcommons.usf.edu/abo/vol1/iss1/7

This New Media is brought to you for free and open access by Digital Commons @ University of South Florida. It has been accepted for inclusion in ABO: Interactive Journal for Women in the Arts, 1640-1830 by an authorized administrator of Digital Commons @ University of South Florida. For more information, please contact digitalcommons@usf.edu. 


\section{Numbering the Streaks on a Digital Tulip: Eighteenth-Century Women Poets on the World Wide Web}

\section{Keywords}

Aphra Behn, digital collections, hypertext, women's poetry

\section{Creative Commons License}

\section{(c) $($ ) $\odot$}

This work is licensed under a Creative Commons Attribution-No Derivative Works 3.0 License. 
The business of a poet, said Imlac, is to examine, not the individual, but the species; to remark general properties and large appearances: he does not number the streaks of the tulip, or describe the different shades in the verdure of the forest. He is to exhibit in his portraits of nature such prominent and striking features, as recall the original to every mind; and must neglect the minuter discriminations, which one may have remarked, and another have neglected, for those characteristicks which are alike obvious to vigilance and carelessness.

—Samuel Johnson, Rasselas

Why would anyone want to write poetry depicting the streaks on a tulip when, with simple search terms ("tulip streaks") entered into Google images, she or he immediately has access to about 22,900 images like these?

\section{http://www.flickr.com/photos/51405405@N00/145081000}

http://home-and-garden.webshots.com/photo/2776166890033656815QenAba

http://www.flickr.com/photos/k2ski/3506307852/

http://home-and-garden.webshots.com/photo/1388322249065699867UfwDnW

http://www.flickr.com/photos/saffsd/2390927075/

How much would one of these images - or all 22,900 of them-have altered Imlac's theory of poetry? Would he have suddenly decided that there's a value in numbering the streaks of the tulips since anyone with a computer and Internet access can verify what the tulip looks like? Or would he have positioned himself even more staunchly in favor of the general, seeing how many vicissitudes and particulars search engines engender at the click of a mouse?

In the context of Aphra Behn Online's “New Media” section, bringing Imlac's assessment of poetry to bear on modern configurations of eighteenth-century women's poetry on the Web may help us open a sequence of interrelated questions about the theory and practice of women's poetry, particularly as the contours of women's writing have expanded with new technologies both of gendered identity and textual practices. Eighteenth-century women's poetry has been the subject and object of digitization, and this process has helped make accessible what was once confined to archives. Beyond making available texts by the lesser-known contemporaries of those epoch-defining, canonical male authors like John Dryden, Alexander Pope, and Samuel Johnson, though, the Internet has helped scholars pose new sets of theoretical questions that specifically line up with feminist epistemologies.

Margaret J. M. Ezell and George Justice have been key questioners of how texts begin to lose their boundaries when we occupy hypertextual worlds. In Justice's, words: "hypertext and its machinery of production, primarily the World Wide Web accessible through the Internet” at first glance seems to challenge or perhaps even dismantle the "ideology of the creative author" (3). Authors as such disappear as we lose the literal, physical covers of the books that confined their 
works, and we are left struggling to either retain or rearrange the textual bodies that have occupied so much of our scholarship.

Aphra Behn, whose remains have always possessed something of the wild intertextuality that the World Wide Web has made a ubiquitous part of everyday life, has acquired proliferative afterlives (to paraphrase Jane Spencer's 2000 study Aphra Behn's Afterlife). Behn has become a lesbian love poet and a space pirate, among the hundreds of thousands of results that come up when one searches for her on Google). Her poetry is as accessible in popular sites as it is in academic ones, and sometimes more so. Since the Brown University Women's Writers Project and the Orlando Project are subscription-only databases, the meticulous work that has produced full-text editions of her work on Brown's site and contextualizing apparatuses on the Orlando Project's site remain archives in the sense of the term as it is used by research libraries, whereas pages like the "Isle of Lesbos" and Wikipedia's Behn page are two of the first hits connected to her name. ${ }^{1}$

This is not to discount the tremendous and transformative effects that digital collections including the Brown University Women Writers Project, Early English Books Online, Eighteenth-Century Collections Online, the Emory Women Writers Resource Project, and the Perdita Project have had on the way we study eighteenth-century women, their writing (for this issue, with a focus on their poetry), and their worlds. Within academic communities, the increasing availability of women's manuscript writings and materials once treated as ephemera, such as recipe books, has helped scholars address the artificiality of textual hierarchies in new ways. In other words, we can begin to locate and theorize overlaps and slippages among women's private and public forms, and we can break texts down in order to reassemble them with a difference-both practices envisioned by feminist literary theory for decades now. The searchability of the Brown University Women Writers Project, for example, allows scholars to search for terms in hundreds of years of text. Discovering shared terms between a gynecology book and a sonnet sequence helps us unearth more about the material practices surrounding the production of women's poetry; locating connections between Behn's verse compilations and religious tracts and cookbooks highlight the artificiality of the boundaries between texts and documents, between literary artifacts and remnants of lives. Brown's site allows for textual breakdown that engenders new forms of synthesis.

At the same time, Behn's poetry circulates on many poetry websites where it can be rated (“A Thousand Martyrs Have I made” receives a 5.9 of 10 on the Poem Hunter website), sent as an ecard, emailed, or printed. The "business of the poet" in this context is to offer a Hallmark-style greeting or an inspiring quotation. This has been true for canonical male poets for some timewho hasn't received a greeting card with a poem by Shakespeare or Wordsworth pared down to a platitude? The fact that mass digitization makes women's poetry as widely available allows for the same commercialization, which could eventually translate into a derogation of the visibility that continues to keep the canon in place despite academic efforts at expansion.

As Aphra Behn Online experiments with the possibilities of online publication for a refereed academic journal, we also invite essays that explore the changing nature of how we study women's writing under the broader umbrella of new media studies. With Behn on our masthead, I see some connections to André Richard's webcomic “Aphra of the Seven Stars," in which Behn 
is imagined as an "intrepid space pirate.” Richard's Behn is very different from the Behn that I love. She is much more anime, a space pirate created for male pleasure. Yet she also reminds me of how manufactured any incarnation of Behn, any embodiment of her, must be. The createdness of her body in Richard's comic in some ways parallels our enduring efforts to create the canon of her poetry, to sort out John Wilmot, Earl of Rochester's words from her own and to establish authenticity of her works.

Returning to the image of the digital tulip, I want to argue that these digital images cannot replace the texts we have studied. But we also need to acknowledge the new ways of looking at authors and their works that the Internet doesn't just facilitate-it requires these tactics. We cannot simply cut and paste words from the Web; we need to develop theories that ensure rich debates about the expanding archives we have at our fingertips, whether they treat eighteenthcentury women's poetry with academic precision or with swashbuckling style. In subsequent issues of Aphra Behn Online, we hope to solicit submissions that address the changes new media forms have engendered in relation to how we read and write about eighteenth-century women, their works, and their worlds. 
ABO: Interactive Journal for Women in the Arts, 1640-1830, Vol. 1 [2011], Iss. 1, Art. 7

\section{Notes}

1. Many sites blur the boundaries between popular and academic configurations, including pages like Jack Lynch’s annotated bibliography of Oroonoko. 